\begin{tabular}{ll} 
& \multicolumn{1}{c}{ RESEARCH ABSTRACT } \\
RESEARCH TITLE: & FACILITATION SKILLS OF GRADE SCHOOL TEACHERS IN \\
& INCREASING LEARNING RETENTION AMONG GRADE \\
& SCHOOL PUPILS IN LUCENA CITY \\
RESEARCHER: & GARRY C. LINGON \\
DATE: & OCTOBER 2014
\end{tabular}

Based on the results of the study, teachers give pupils an ample time to discover new things on their own. Besides, the way of how the teachers facilitate the learning process might affect the academic performance of the pupils. Consequently, it comes in challenges being faced by the teachers in the facilitation of the learning activities of learners such as planning, creating, preparing, and selecting the materials used on it. Moreover, teachers necessary to consider the student's need for making learning activities. This activity must suit the capability of the learners, adapt to the different learning styles, and especially it is must stimulate the interest of the learners. Although not all activities are suited for all learners because learners are diverse and unique in nature. hence, the needs of pupils are the major concern of the teachers, to assure that the students learn and this learning could apply in their daily lives for meaningful learning. Further, research dealt with the challenges of the teachers in increasing the learning retention of pupils and determine the possible activities employed by the teachers in stimulating the interest of the learners. This research measure the responses measured in getting the frequency, percentage, and weighted mean using formulas to analyze the data gathered. Utilize descriptive design with a survey questionnaire as the research instrument. This research has two sets of respondents the grade school teachers and pupils.

\title{
INTRODUCTION
}

In the usual way of teaching, the teachers are spoon-feeding the information to the students. This means that the teachers are the one who discusses the lesson and the students are merely listening to it. This way is not enough in the development of students holistically. In the $20^{\text {th }}$ century, teaching is entirely different in the traditional way of teaching. In line with this, the teacher must use a varied activity and strategy that give the students a wider horizon of learning and experiences. Further, the trend of education are changing, the students discover their understanding through the guidance of their teachers. In that case, teachers are the facilitator of learning.

Moreover, Tenedero (2011) said that most teachers know what to teach, but don't realize that they can't possibly know how to teach it without first identifying how their children learn. Moreover, Arellano (2006) states that the child's basic needs are the powerful underlying basis for all activity, become an essential factor in determining all learning practices and procedures.

Because of the aforementioned though, it is the pressing concern of the educators to meet the needs of the learners to catch up to the lesson and increase the learning retention among pupils. For that reason, the challenges come in the teachers should address it to attain the highest potential of the students.

In connection with this, a teacher should be innovative and creative in addressing the needs of the students. With this, being a facilitator it should be a deep understanding of the principles of teaching. It should be exerting effort and time on developing the abilities and potentialities of the learners through effective facilitating of the learning process. The teachers were concerned about the development of cognitive, affective and psychomotor skills of pupils. 
The researcher intends to address the challenges faced by the teacher in facilitating learning. Also, this research is intended to showcase the strategies that may be employed by the teachers in coping with the challenges in facilitating learning. Mainly, in this study also the researcher wants to know that the facilitation skills of teachers could affect the academic performance of the pupils.

\section{Statement of the Problem}

This study aimed to identify the challenges encountered by the teachers in increasing learning retention of grade school pupils.

Specifically, the study sought to answer the following questions:

1. What is the demographic profile of the teacher- respondents in terms of the following?

For the Teachers

1.1. Age

1.2. Gender

1.3. Educational Attainment

1.4. Length of Teaching

\section{For the Students}

1.5. Gender

1.6. General Average Last Years

2. What were the challenges faced by teachers in facilitating the activities of the pupils?

3 . What are the teachers' ways of coping with these challenges in facilitating the activity?

4. What are the characteristics of effective learning activities?

5. What are the effects of the facilitating skills of the teachers in the academic performance of the pupils?

\section{Conceptual Framework}

Tenedero (2011) shared that passion is an intense feeling or conviction, a strong link, and desire for or devotion to some activity, object, or concept. When we communicate with passion, we share with others the same intense conviction, enthusiasm, and powerful emotions that we feel regarding a subject. With this, the teacher should convince the pupils that the lesson is interesting through the strategy that will arouse the attentiveness of the pupils in the lesson. The passion of the teacher in teaching the pupils that contribute to developing the interest of the pupils. In the idea of Tenedero assert the communication between the teachers and students is really important in the learning process.

Likewise, Tenedero (2012) emphasized that a highly motivated teacher excites and emotionally provokes students to learn. A boring teacher produces a boring class. The teacher needs to update their facilitating skills and be worth listening to. Students can attain optimal learning and memory retention given meaningful and positive classroom climate, like positive comments, joyfulness, childlikeness, social acceptance, enthusiasm, and stimulating challenges. In connection with this, teachers should be shown enthusiasm in teaching that stimulates the interest of the learners through this the learning retention is being increased. 
In connection with the aforementioned thought, Corpuz (2012) discussed that constructivism knowledge isn't a thing that can be simply deposited by the teacher into the empty minds of the learners. Rather, knowledge is constructed by learners through an active, mental process of development; learners are the builders and creators of meaning and knowledge. Their minds are not empty. Instead, their minds are full of ideas waiting to be "midwife" by the teacher with his/ her skillful facilitating skill. In the concept of Corpuz, pupils have their prior knowledge that the teachers should be hone and develop through their guidance. Through this, teachers should think of the way that prior knowledge of the pupils could connect to the present lesson that the teachers teaching. Thus, meaningful learning occurs.

It is supported by Tejero, Tejero Jr., Tejero- Giray (2012) teaching to be effective, must follow a well- organized process and system of activities that would facilitate and evaluate learning in the students. It should be based on established principles and psychological theories which seen to be effective in facilitating learning. Indeed, there are many ways through which teachers can deliver knowledge, skills, and appreciation to the students.

In the world of teaching, there are a lot of challenges met in facilitating learning. The teachers should revisit their techniques in delivering their lessons. In that case, the task of the teachers is multi-faceted because of the things he/she need to attain for the pupils to learn from the lesson. Especially, the teacher should establish effective facilitating learning to increase the learning retention among the pupils.

\section{Conceptual Paradigm}

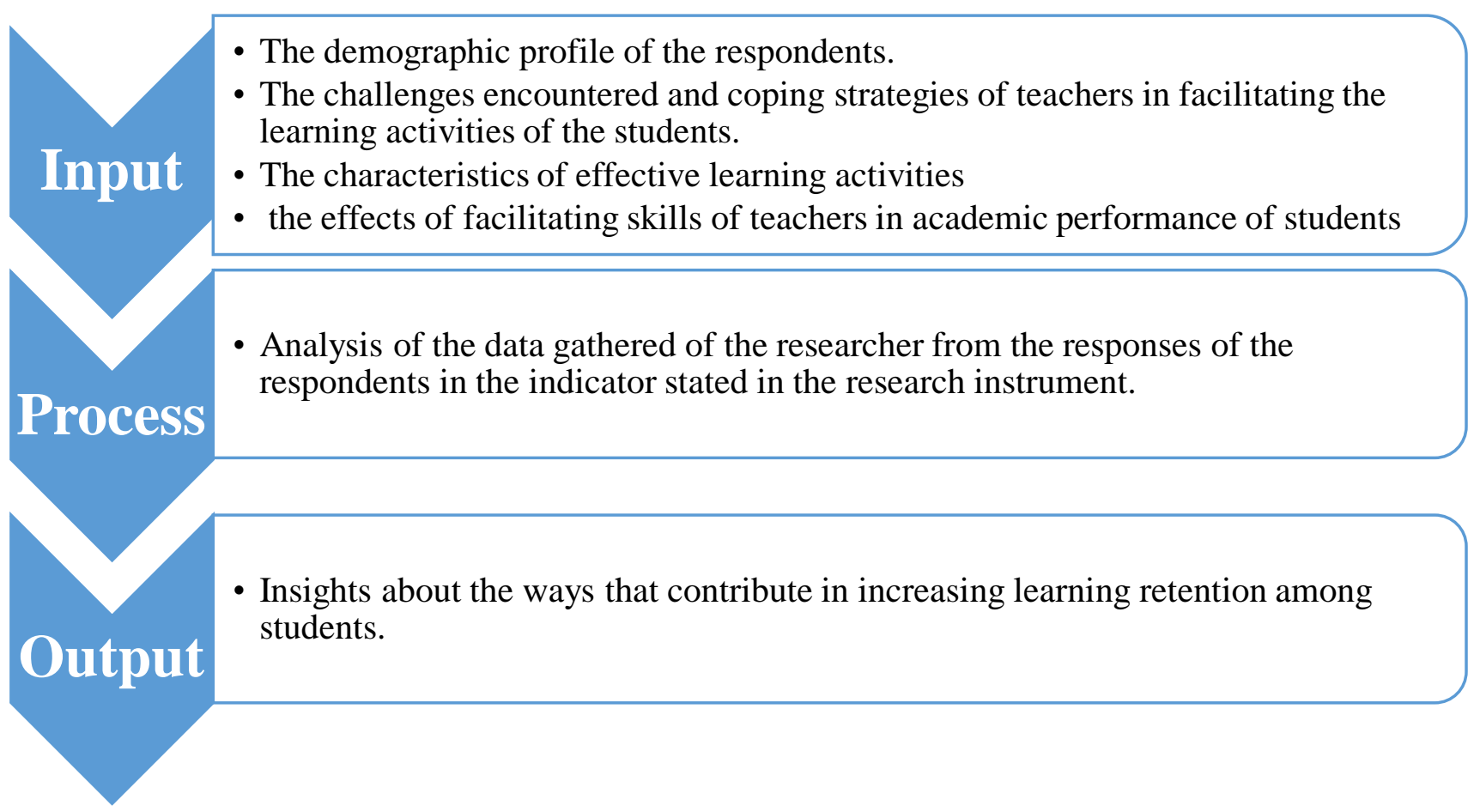

Figure 1. The conceptual paradigm shows the challenges encountered by grade school teachers in facilitating the learning among grade school pupils to increase their learning retention. 


\section{RESEARCH METHODOLOGY \\ Research Design}

The researcher used a descriptive design of research to find out the challenges of teachers in facilitating the learning activities in increasing learning retention among grade school pupils. It involves getting the percentage and frequency distributions of the responses, tabulation, making of the tables to compare and make the data concise, and analysis of the data gathered.

\section{Research Population}

The populations used in the study were the grade school pupils and teachers of one public school of Lucena City. It is composed of different sections such as St. Paul has 51 pupils, St. Claire with 44 pupils, St. Therese with 44 pupils, and St. Anne composing of 38 pupils and their five teachers. Summing it up, this study involves 177 pupils and five teachers as the respondents.

\section{Research Locale}

The research locale is located in Ibabang Dupay, Lucena City. This institution has a huge number of students who are enrolled in this institution. In that case, the teacher has a hard time to teach and facilitate learning to the pupils. This is the prompted the researcher to conduct this study to help the teacher to cope with the challenges met in facilitating learning among students.

\section{Research Instrumentation}

The researcher used questionnaires as the data gathering instruments of this study.

The questionnaires are divided into two sets: one for teachers and the other set for the pupils. The researcher used the Likert scale for instrumentation. The first part encompassed the demographic profile of the respondent.

The questionnaire dealt with the following parts: Part II- Learning Activities, Part III- The challenges experienced by the teachers in facilitating the activity, Part IV- Teachers' way of coping with the challenges in facilitating the activity (Part II, III and IV for teacher-respondents) and Part $\mathrm{V}$ - The effects of facilitating skill of teachers in academic performance of pupils. The respondents just check his/her responses that corresponds to their answer.

\section{Data Gathering Procedure}

In accomplishing this study, the following procedures were considered:

The researcher sought the approval of the principal in the research locale. After receiving the approval, a copy of the questionnaire was given to the respondents of the study which were the Grade school teachers and pupils. The questionnaires were personally administered by the researcher to the respondents to assist the respondents if they are any question about the questionnaire.

The distribution of the questionnaires was done in the vacant time of the respondents. They were given ample time to accomplish the research instrument to ensure the reliability of data. Afterward, the questionnaire was personally retrieved by the researcher tallied and statistically 
treat the responses of the respondents.

\section{Statistical Treatment}

To find out the result of the data gathered, statistical analysis was conducted and the formulas used are the following:

1. Weighted Mean

$\mathrm{WAM}=5 f+4 f+3 f+2 f+1 f$

$N$

Where:

$f$ - Frequency responses

$\mathrm{N}$ - Total number of the respondents

2. Mean Distribution

$$
\text { Mean }=\frac{\in F x}{\mathrm{~N}}
$$

Where:

$\mathrm{X}=$ Scale

$\mathrm{N}=$ Number of respondents

3. Percentage Distribution

$$
\mathrm{P}=\frac{\mathrm{F} X 100}{\mathrm{~N}}
$$

Where:

$\mathrm{P}=$ Percentage

$\mathrm{F}=$ frequency

$\mathrm{N}=$ number of respondents

\section{SUMMARY OF FINDINGS}

Ethical Approval

Written informed consent was obtained from all participants. All procedures performed in the study involving human participants were following the ethical standards of the institution and/or the oral examination committee. As a response to the privacy of the respondents and research locale, the researcher did not indicate the name of the respondents and research locale throughout the research. Especially, all the consent forms and other documents did not indicate in the study to protect the name of the institution and respondents. 
The general findings of this study were stated as follows:

Part I- Demographic Profile of the Respondents for the Teachers

Age

The finding shows that only 1 or $20 \%$ of the respondents $20-25$ years old, 31-35 years old and 46-50 years old were gathered 2 or $40 \%$. This shows the most frequent age bracket are 31-35 years old and 46-50 years old.

\section{Gender}

From a total of five (5) teacher-respondents, two (2) or $40 \%$ were male. The remaining $60 \%$ or a total of three (3) respondents were female. The result shows that the female populace is dominant than males.

\section{Educational Attainment}

The whole populace of the grade 5 teacher has a master's degree unit gathered 5 or $100 \%$. The result shows that grade school teachers in Lucena City are currently taking a master's degree.

\section{Length of Teaching}

The finding shows that there is 1 or $20 \%$ of the teacher-respondents were 16-20 years in the service. 6-10 years and 11-15 years were gathered two (2) or 40\%. The longest years in the service were 16-20 years old.

\section{For the Students}

Gender

From a total of one hundred seventy-seven (177), ninety-three (93) or 52.54\% were males. The remaining $47.46 \%$ or a total of eighty-four (84) were female. The result shows that the male populace is dominant than females.

\section{General Average Last Year}

Finding shows that there are three (3) students or $16.94 \%$ of the respondents were obtained a grade 75 below. Thirty-seven or $20.90 \%$ of the respondents got a grade of 75-79. One hundred three (103) or $58.19 \%$ of the respondents got 80-84. Thirty-three (33) or $18.64 \%$ got a grade of 85 89 and one (1) or $0.56 \%$ got $90-95$. The dominant grade bracket is $80-84$. (Part II, III and IV for teacher-respondents and Part V for student-respondents)

\section{Part II - Learning Activities}

Item no. 2 which state "All learners must actively participate in the activity" and item no. 7 which state "Uses a variety of activity" were ranked first with a weighted mean of 5.

The item no. 8 which state "In choosing activity, should select those respond the needs of learner, item no. 9 which state "Discover new knowledge while working their activity" and item no. 10 which state "Pupils interact to other pupils while working the activity" were ranked fourth with 
the weighted mean of 4.80 .

The item no. 1 which state "Activity must anchor in real-life context", item no. 4 which state "Pupils must have ample time to work the activity, and item no. 6 which is "Pupils connect their prior knowledge in engaging the activity" were ranked seventh with a weighted mean of 4.60. Item no. 3 which state "Most of the activity done in the group" were ranked 9 with a weighted mean of 4 and the item no. 5 which state "Activity fostering problem-based" was ranked tenth with a weighted mean of 3.80 .

\section{Part III - The Challenges of Teacher in Facilitating the Activity}

Item no. 1 which states "Managing discipline of pupils while working the activity", item no. 2 which states "Sustaining Attention of the pupils", statement no.6 which is "It the teacher should be patience in facilitating the learning activity", item no. 7 which state "The activity must adapt to the different learning style", item no. 8 which state "Participation of the pupils in the activity", item no. 9 which state "Selection of appropriate material use in the activity" and item no. 10 which state "Guide the pupils to do what needs to be done" was ranked fourth with a weighted mean of 5 .

Item no. 3 which state "Designing learning task that needs collaboration" were ranked eighth with a mean of 4.80 .

Item no. 4 which states "Different receptors in implementing the activity" and item no.5 which states "Organize a variety of grouping of the pupils" was ranked ninth with a weighed mean 4.10.

\section{Part IV - Teachers' Way of Coping Challenges in Facilitating the Activity}

Item no. 1 which states "Monitor the progress of the activity", statement no. 5 which state "Get the attention of learner", item no.7 which state "Find appropriate activity that is suited to the learners", item no. 8 which state "Give learner opportunity to discover their own knowledge", and item no. 9 which state "Connects the prior knowledge of the learner to the lesson" were ranked third with a mean of 5 .

Item no. 2 which states "Explain the step-by-step procedure", item no. 6 which states "Priming students' motivation the activity" and item no.10 which states "Foster positive atmosphere among students" were ranked seventh with a weighted mean of 4.80 .

Item no. 4 which states "Accommodate the question of pupils before the activity" was ranked ninth with a weighted mean 4.60 and item no. 3 which state "Solicit Feedback" was ranked tenth with a weighted mean of 4.40

\section{Part V- The Effects of Facilitating Skills of Teachers in Academic Performance of Pupils}

The item statement no. 15 which states "I join activities because it develops my skill" was rank first with a weighted mean of 4.12 .

Item no. 3 which states "I become active in class" were ranked 2 with a weighted mean of 4.04 and item no.9 which states "I share my knowledge to my group about the activity" were 
ranked third with a weighted mean of 4.03.

The item no. 1 which state "I participate in group activity" were ranked fourth with a weighted mean of 3 The item no. 4 which state "I motivated to work my activity" and item no. 8 which state "I pay attention to our activity" was ranked fifth with a weighted mean 3.93.

Item no. 14 which states "I become creative" were ranked seventh with a weighted mean of 3.89, item no. 11 "I discover new knowledge while I work my activity" were ranked eighth with a weighted mean of 3.77, the item no. 5 which states "I always accomplish the activity" was ranked ninth with a weighted mean of 3.76, item no. 7 which states "I connect my prior knowledge in our activity" were ranked tenth with a weighted mean 3.75 , the statement no. 12 which state " I can apply my learning in my daily lives" were ranked eleventh with a weighted mean 3.71 , the item no. 6 which state "I can recall my past lesson" and item no. 13 which state "I am guided by my teacher when if I have hardship in the lesson" were ranked twelfth with a weighted mean of 3.60, the item no. 10 which state "I give feedback about the activity, if necessary were ranked fourteenth with a weighted mean of 3.55 , and last the item no. 2 which state "I ask my teacher for clarification, if necessary was ranked fifteenth with a mean 3.38 .

\section{CONCLUSIONS}

After an interpretation of the data gathered, the study shows:

\section{For the Teachers}

1. The frequent age of the teachers are 41-45 years old and 46-50 years old, most of the teachers are female, all of the grade school teachers in Lucena City are currently taking a master's degree and length of the teaching of teachers are ranging 6-10 years and 11-15 years.

2. The indicator of the effectiveness of the learning activities are the following: all learners must actively participate in the activity and uses a variety of activity.

3. The main challenges that encountered by the grade school teachers in facilitating learning activities are the following: Managing discipline of pupils, sustaining attention of the pupils while working the activity, it involves patience in facilitating activity, the activity must be adapted to the different learning style, the participation of the pupils in the activity, selection of appropriate material use in the activity, and guide the pupils to do what needs to be done.

4. The way of teachers in coping the challenges in facilitating learning activities are the following: Monitor the progress of the activity, get the attention of learners, and find an appropriate activity that suited to the learners, give learner opportunity to discover their knowledge and connects the prior knowledge of the learner to the lesson.

\section{For the Students}

1. Male is dominant than female in terms of the distribution of respondents in gender. The frequent general averages last year of the pupils were 80-84.

2. The effects of facilitating skills of teachers in the academic performance of pupils are the following: I join activities because it develops my skill and I become active in the class.

3. The learning retention occurs when having a positive classroom climate, they can connect their 
experiences in the lesson/ activity and stimulate challenging activities.

\section{RECOMMENDATIONS}

Based on the findings and conclusions the following recommendations made:

\section{For the Teachers}

1. Explain the rule to follow and expectations to be done by the pupils in the activity.

2. Space out humor to catch up the attention of pupils in the lesson/activity.

3. Be patience all the time.

4. Use a variety of learning activities.

5. Encourage the pupils to participate in the activity.

6. Survey on the needs of pupils and decide the material used.

7. Solicit feedback after the activity, for improvement.

\section{For the Students}

1. Ask for assistance if have hardship in the activity.

2. Rehearse the information learned in the activity.

3. Associate new learning with already known.

4. Utilize study routine.

5. Ask the teacher for clarification before to start the activity.

\section{BIBLIOGRAPHY}

\section{Books}

Agno, L. N. (2010). Principles Teaching 2 A Modular Approach. Quezon City: C \& E Publishing, Inc.

Aquino, A. M. (2009). Facilitating Human Learning. Sampaloc, Manila: Rex Book Store.

Bilbao, P. P., Corpuz, B. B., Llagas, A. T., Llagas G. G. (2012). The Teaching Profession (2 ed.). Quezon City: Lorimar Publishing, Inc.

Kahayon, A. H., Berba, M. T. V. (2007). Psychology Towards A New Millennium. Mandaluyong City: National Book Store.

Leviste, J. V. (2010). How to Teach the Filipino Preschool. Quezon City: Rex Book Store, Inc.

Lucas, M. D., Corpuz, B. B. (2007). Facilitating Learning: A Metacognitive Process. Lorimar Publishing, Inc.: Quezon City.

Tejero, E. G, Tejero, Sr. P. D., Giray, Z. M. T. (2012). Multi-Disciplinary Teaching Strategies. Mandaluyong City: National Book Store.

Vega, V. A., Prieto, N. G. (2006). Facilitating Learning. Mandaluyong City: Books Atbp. Publishing Corp.

Zulueta, F. M., Sevilla, Z. V. (2012). Principles of Teaching and Teaching Strategies. Mandaluyong City: National Book Store. 


\section{Magazines}

Adduru, M. Q. (2006). What Affects the Achievement Level of a Learner? The Modern Teacher, p. 94.

Antiquina, P. S. (2006). An Effective Teacher. The Modern Teacher, p. 318.

Apolonio, A. O. (2006). Understanding the Filipino Leaner. The Modern Teacher, p. 91.

Arellano, R. (2006). Making Classrooms Conducive for Learning. The Modern Teacher, p. 313.

Beltran, C. R. (2006). How to Increase Participation in Lessons. The Modern Teacher, p. 93.

Casillan, D.P. (2006). Motivation in Teaching and Learning. The Modern Teacher, p. 314.

Dela Cruz, J. A. (2006). 10 Ways on How to Become an Effective Professional Teacher. The Modern Teacher, p. 316.

Gonzales, A. L. (2006). How to Become Effective in the Classroom. The Modern Teacher, p. 321.

Lumboy, H. S. (2006). Deciphering Effective Learning. The Modern Teacher, p. 312.

Santiago, R. R. (2006). The Concept of Mastery Learning. The Modern Teacher, p. 311.

Seroy, J. L. (2006). Learning Style, Stress management and Teaching Strategies: Making Classroom Teachers Effective. The Modern Teacher, p. 323.

\section{Articles}

Goze, I. P. (2008). Teaching Method: Piaget Active learning. p. D1.

Jugueta, A. U. (2008). Competency-based Approach to Effective Teaching and School management as Experienced by School Teachers and Administrators in Region IV.

Mabuti, M. C. (2013). Ode to the Teacher. Teachers and Teaching 2, p. M4.

Tenedero, H. S. (2005). Teaching the Unattentive. Breakthrough Education, p. B8.

Tenedero, H. S. (2005). Motivating the Uninterested. Breakthrough Education, p. B7.

Tenedero, H. S. (2008). Designing Effective Presentations. Breakthrough Education, p. E2.

Tenedero, H. S. (2008). Learning and Mobility. Breakthrough Education, p. F2.

Tenedero, H. S. (2009). Learning with Purpose. Breakthrough Education, p. E2. p. E2.

Tenedero, H. S. (2009). Six Ways to Bring out your Best. Breakthrough Education, p. E2.

Tenedero, H. S. (2010). What are your child's environmental preferences? Breakthrough Education, p. E2.

Tenedero, H. S. (2012). The Role of Emotions in Learning. Breakthrough Education, p. F2.

Tenedero, H. S. (2012). Learning Retention Rate Levels. Breakthrough Education, p. 11.

Tenedero, H.S. (2011) Using Passion and Laughter in Presentations. Breakthrough Education p. E2.

Tilestone, D. W. (2012). What Evey Teacher Should Know About Effective Teaching Strategies. California: Corwin Press A Sage Publications Company Thousand Oaks.

\section{Electronic Resources}

Bernaus, M. (2008). Teaching vs. Facilitating. Retrieved July 2, 2014, from 
http://www.google.com.ph/url?sa=t\&rct=j\&q=\&esrc=s\&source=web\&cd=1\&cad=rja\&u act $=8 \&$ ved $=0 \mathrm{CBoQFjAA} \& u r l=\mathrm{http} \% 3 \mathrm{~A} \% 2 \mathrm{~F} \% 2 \mathrm{Fwww} \cdot \mathrm{coe}$. int $\% 2 \mathrm{Ft} \% 2 \mathrm{Fdg} 4 \% 2 \mathrm{Feducati}$ on\%2Fpestalozzi\%2FSource\%2FDocumentation\%2FALFJuly2008\%2FALFJuly2008_M erce2.ppt\&ei=RvGzU_eFO8KcugSJ94KYBA\&usg=AF

Unknown (n.d.) Critical Issue: Building on Prior Knowledge and Meaningful Student Contexts/Cultures. Retrieved August 6, 2014, from http://www.ncrel.org/sdrs/areas/issues/students/learning/lr100.htm

De la Varre, C., Keane, J., Irvin, M. (2011). Dual Perspectives on the Contribution of On-Site Facilitators to Teaching Presence in a Blended Learning Environment. 25(3), Pages. Retrieved July 23, 2014, from http://search.proquest.com/docview/1017873976?accountid=146485

Ditlhake, B. M. (2001). The Facilitation of Creative Problem-Solving Skills for Learners in Further Education and Training. Retrieved July 12, 2014, from http://upetd.up.ac.za/thesis/submitted/etd-12092005-112829/unrestricted/dissertation.pdf

Unknown (n.d.). Instructional Design: Facilitation Theory. Retrieved July 28, 2014, from http://teorije-ucenja.zesoi.fer.hr/doku.php?id=instructional_design:facilitation_theory

Gray, A. (n.d.). Constructivist Teaching and Learning. Retrieved August 6, 2014, from http://www.saskschoolboards.ca/old/ResearchAndDevelopment/ResearchReports/Instruct ion/97-07.htm

Kinshuk, S. G., Zhang, Q., Maguire, P., Shtern, V. (n.d.). Facilitating Learning Through Dynamic Student Modelling of Learning Styles - An Architecture and its Application for Providing Adaptivity. Retrieved July 23, 2014, from http://sgraf.athabascau.ca/publications/graf_etal_TLIW11.pdf

McKimm, J., Jollie, C. (2007). Facilitating Learning: Teaching and Learning Method. p. 6. Retrieved July 11, 2014, From http://www.faculty.londondeanery.ac.uk/e-learning/smallgroup-teaching/Facilitating_learning_teaching_-_learning_methods.pdf

Meier, K. S. (2013). Basic Class Facilitation Skills for Elementary Teachers. Retrieved July 23, 2014, from http://www.ehow.com/info_12314519_basicclass- facilitation- skills elementary-teachers.html

Ngonyani, M. S. (2010). Teachers' Facilitation of Learning for Learners and Disabilities in Inclusive Classroom. Retrieved from https://www.duo.uio.no/bitstream/handle/10852/32250/MussaxShaffiixNGONYANIxxM asterxsxThesisxxM.xPhil.xSNEx.pdf?sequence $=1$

Peck, C. (2001). Christoper Peck. Holistic Solution. Retrieved July 13, 2014, from http://www.holistic-solutions.net/Articles/DevelopArtofTeaching.pdf

Romano, L., Papa, L. Saulle. (n.d.). 6 Awesome Cooperative Classroom Games. Retrieved September 9, 2014, from http://www.teachhub.com/6-awesome-cooperative-classroomgames

Tinzman, M. B., Jones, B.F., Fennimore, T. F., Bakker, J., Fine, C., Pierce, J. (1990). What Is the Collaborative Classroom? Retrieved August 6, 2014, from http://methodenpool.uni- 
koeln.de/koopunterricht/The\%20Collaborative\%20Classroom.htm

Sanders, B. (2014). Strategies For Improving Learning and Retention. Retrieved July 22, 2014, from http://www.ehow.com/way_5775448_strategies-improving-learning-retention.html

Shiffon, C., Atasi, M., Bani, B. (2011). Peer Collaboration, Facilitator Intervention, and Learning Styles in Computer Game-Based Learning: Initial Findings From an Empirical Study. European Conference on Games Based Learning (pp. 683-XI). Academic Conferences International Limited. Retrieved July 23, 2014, from http://search.proquest.com/docview/1009900808?accountid=146485

Thomas, G. (2008). A study of the Theories and Practices of Facilitator Education. Retrieved July 13, 2014, from https://www.academia.edu/409203/Evaluative_study_of_secondary_school_teachers_ competency_in_english

Unknown (n.d.). Promoting effective classroom participation. Retrieved September 2, 2014, from https://uwaterloo.ca/centre-for-teaching-excellence/teaching-resources/teachingtips/assessing-student-work/grading-and-feedback/promoting-effective-participation

Unknown (n.d.) Workshop Resources 1: Creative Facilitation Technique. Retrieved July 23, 2014, from http://www.teindia.nic.in/files/teacher_trg_module/8_creative_facilitation_techniques.pdf Workshop: Cooperative and Collaborative Learning (n.d.). Retrieved September 9, 2014, from http://www.thirteen.org/edonline/concept2class/coopcollab/index_sub3.html 